\title{
REPORT OF LEPROSY SURVEY IN THE AMADI DISTRICT, EQUATORIA PROVINCE, S. SUDAN
}

\author{
A. J. Sowden.
}

The inhabitants of this area are an agricultural people; during the dry season they are rather widely scattered, being engaged in hunting, work for their Chiefs, and Government road work; with the onset of the rains they return to their villages to undertake their farming for the year.

Having these facts in mind I decided to embark upon my work of surveying the Moru people within the Lui-Amadi area at the coming of the present rainy season.

The survey of the people of three Chiefs, Jambo, Luka and Aganwa has been completed, and that of the people of Wajo and Ngeri is in hand. In each case, prior to commencing the survey I have visited the Chief and requested a meeting with him and his Sub-Chiefs. At this meeting the need for the survey 
was stated and the fact stressed that without the full co-operation of the Chiers it would be useless. I asked the Chiefs to appoint meeting places where their people could foregather for inspection; on no account were these to involve the people in more than two hours walking.

The object of this condition was to avoid taking the people away from their work on the farms for any undue length of time. That this has been worth while is evident from the large percentage of people seen, though it has involved long journeys into the forest and eight to ten hours walking per day for a week at a time. This was particularly necessary when working in the area in the vicinity of Lui-Chief Luka's people. Here the younger generation have left the roads in the search for virgin soil to farm, and on two occasions I was "out in the blue" for a week. These people would not have come in unless force had been used-the offer of a policeman from Amadi was refused on the grounds that his presence would tend to create a fear of segregation in the minds of both known and new cases of leprosy. Undoubtedly the method used gave confidence; it is believed that there were very few attempts made to conceal the disease, and several crippled cases were so eager to be seen that they had their relatives carry them either to the roadside or the meeting place.

The attitude to leprosy in the Sudan favours the spread of the disease. It is in marked contrast to that which prevails in Nigeria where in every community there is a very obvious fear of leprosy. There, once discovered to be a leper, the victim is obliged in the majority of cases to leave his village and live in the bush, and various settlements were begun through cast-out lepers combining and building villages for their own protection. Very little evidence of such fear has been discovered during the present survey. The most infectious lepers are permitted to mix freely with their fellows. A case in point is that of a female child of a leper who married when clean, but later when the disease developed was divorced by her husband who, within a year, himself became a leper; recently whilst in another area I came upon the woman who, having once more been divorced, was again married. The husband told the writer that prior to his marriage two years ago he had no known contact with a leper, yet he also now had the disease, moreover two children of these three marriages are also lepers.

Leprosy control in the densely populated areas of Southern Nigeria presents a problem of tremendous magnitude to workers in that country, even though they are aided by the fear of the 
clean and the desire of the lepers for treatment and their willingness to enter settlements. Here in the S. Sudan, though these factors are missing, leprosy control should not present anything like the same problems.

The Morus are much less clanish than the Ibos of Nigeria. They live in small hamlets with rarely more than 50 people in each, more often than not less than I2. Consequently they have ample land for farming, the housing is much better and, whilst there is little or no attempt at sanitation, one does not meet with the vile conditions which are often seen in Nigeria. A scheme for the segregation of infectious lepers such as that operating in the Uzuakoli district, S. Nigeria, ought under these conditions to prove most successful in the matter of leprosy control.

During the surveys I was accompanied by one assistant who was able to take smears; the actual examination was made by the writer. The names of all persons having lesions which could possibly be produced by leprosy were noted and, when all the people present had been seen, these were re-examined and slides taken. The 1939 census was used and every effort made to trace and note names of any absentees; the Chiefs co-operated very willingly and in the majority of cases the only absentees were men engaged in working in other parts of the province. Any living under another Chief are brought in when that area is visited. A census of the people was made and the age group, reckoned in decades, of each person was recorded at the time of examination. On one or two occasions names were put on the list for observation.

Numbers seen and Leprosy incidence.

Chief Jambo's people.

Total seen (including those of sub-chieftains) ... ... I,7I5

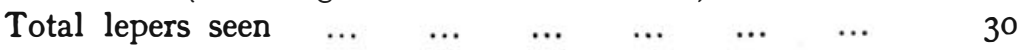
$\begin{array}{lllllllll}\text { Incidence } & \ldots & \ldots & \ldots & \ldots & \ldots & \ldots & \ldots & \mathbf{1} .7 \%\end{array}$

(Of the above 30 lepers, only I2 showed a positive slide)

Chief Juka's people.

$\begin{array}{ccccccccr}\text { Total seen } & \ldots & \ldots & \ldots & \ldots & \ldots & \ldots & \ldots & 5,320 \\ \text { Total lepers seen } & \ldots & \ldots & \ldots & \ldots & \ldots & \ldots & 135 \\ \text { Incidence } & \ldots & \ldots & \ldots & \ldots & \ldots & \ldots & \ldots & 2.5 \% \\ \text { (Of the above, } 50 & \text { lepers } & \text { only } & \text { gave } & \text { a } & \text { positive } & \text { slide) }\end{array}$

Chief Agomzer's people.

$\begin{array}{lllllllll}\text { Total seen } & \ldots & \ldots & \ldots & \ldots & \ldots & \ldots & \ldots & \mathbf{2 , 3 5 0}\end{array}$

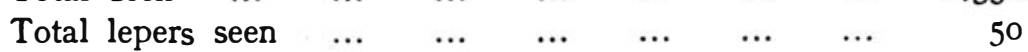

$\begin{array}{lllllllll}\text { Incidence } & \ldots & \ldots & \ldots & \ldots & \ldots & \ldots & \ldots & 2.1 \%\end{array}$

(The examination of the slides of this survey is not yet completed) 
The work of survey will be continued until the end of the rains. With the coming of the dry season the people will scatter and become more difficult to get hold of for examination. If circumstances permit I propose to visit one or other of the two districts of Maridi and Yei early in I94I, proceed with the survey of that district, and return to complete the Moru area in the next rainy season.

With regard to the lepers in the area so far covered, I suggest that a small settlement be established at each of the three places surveyed (certainly two, one at Luka's and the other at Aganwa's), large enough to house the infectious lepers in each case, the Chief providing the labour for the building of the houses. Some arrangement would need to be made whereby the lepers would be assured of a regular weekly supply of grain; the relatives could be made responsible for the supply of other items of food, failure to do so being punishable by the Chief's court. Some assistance with the farming for the following year might be needed; this too could be done with the co-operation of the Chief.

Treatment could be given by the dispenser at the Chief's dispensary, within the vicinity of which the settlement would be erected. If funds were available a well would be an asset. I could return periodically from whichever district I was working in and I feel sure that the Lui doctor would also be willing to visit on the occasions when he paid a visit to his dispensaries. 